\title{
Pesticide Application among Farmers in the Catchment of Ashaiman Irrigation Scheme of Ghana: Health Implications
}

\author{
Memuna M. Mattah, ${ }^{1}$ Precious A. D. Mattah, ${ }^{2}$ and Godfred Futagbi ${ }^{3}$ \\ ${ }^{1}$ Department of Environmental and Development Studies, Central University College, Accra, Ghana \\ ${ }^{2}$ Directorate of Academic Planning and Quality Assurance, University of Cape Coast, Cape Coast, Ghana \\ ${ }^{3}$ Department of Animal Biology and Conservation Science, University of Ghana, Legon, Accra, Ghana \\ Correspondence should be addressed to Godfred Futagbi; gfutagbi@ug.edu.gh
}

Received 7 July 2015; Revised 26 November 2015; Accepted 2 December 2015

Academic Editor: Brian Buckley

Copyright (C) 2015 Memuna M. Mattah et al. This is an open access article distributed under the Creative Commons Attribution License, which permits unrestricted use, distribution, and reproduction in any medium, provided the original work is properly cited.

\begin{abstract}
Pesticide use in modern day agriculture has increased tremendously. Pesticides are used to control pests and weeds, as well as protect crops from postharvest losses; however, their effects on humans and the environment cannot be overstated. This study examined pesticide acquisition, handling, and use among 120 farmers within the catchment of a small urban irrigation scheme. Also, in-depth interviews and focus group discussions were conducted among selected farmers through which further data was collected to augment that of the survey. Twelve types of pesticides, including herbicides, insecticides, and fungicides, were found in use in the study areas. Three main sources of information about pesticides were identified, $43.3 \%$ from extension officers, $39.2 \%$ from agrochemical dealers, and 10\% from colleague farmers. Seventy-five percent (75\%) of the respondents purchased the pesticides from agrochemical shops. Out of 74 farmers who were observed spraying pesticides on their farms, only $25.7 \%$ wore dresses that covered their whole body but without goggles. About sixty-seven percent $(66.7 \%)$ of the farmers whose chemical got finished left the containers on their farms or threw them into the bushes around. The frequency of application was influenced by affordability and size of farm, among others. The study recommended that training of farmers on pesticide handling and use should be intensified.
\end{abstract}

\section{Introduction}

Agriculture remains the main economic stay of Ghana. It employs over $50 \%$ of the labour force and contributes above $20 \%$ to the GDP $[1,2]$. In spite of this, agricultural practices in Ghana remain rudimentary resulting in low yields and productivity [3]. As a way of curbing low yields and productivity, farmers resort to the use of pesticides. Pesticide use among farmers in Ghana has reached its peak in recent years especially for controlling weeds, pests, and preservation of harvested crops [3]. In Ghana, pesticides are applied mainly to cash crops and vegetables [4]. While many farmers lack adequate information about the hazards associated with handling and use of pesticides, several reports discussed the effects of pesticides on the environment and on the health of farmers [5-8].

The government of Ghana in mid-1960s constructed an irrigation dam in Ashaiman, a fast developing city in the Greater Accra region of Ghana. The dam has since its construction helped farmers in Ashaiman and its environs in the cultivation of various crops especially vegetables and rice for the urban market. It is therefore important that the incessant use of agricultural pesticides among the farmers be constantly investigated in order to assess the possible public and environmental health risk that may be associated with their use. This paper is aimed at evaluating the complete chain from information on pesticides, mode of acquisition, handling, use, and disposal of waste containers among farmers in the environs of Ashaiman in Ghana. It was part of a major study on the effect of urbanization on water quality in the Ashaiman Irrigation Scheme.

\section{Methods}

2.1. Study Area. The survey was conducted in four communities found within the catchment of Dzorwulu stream 


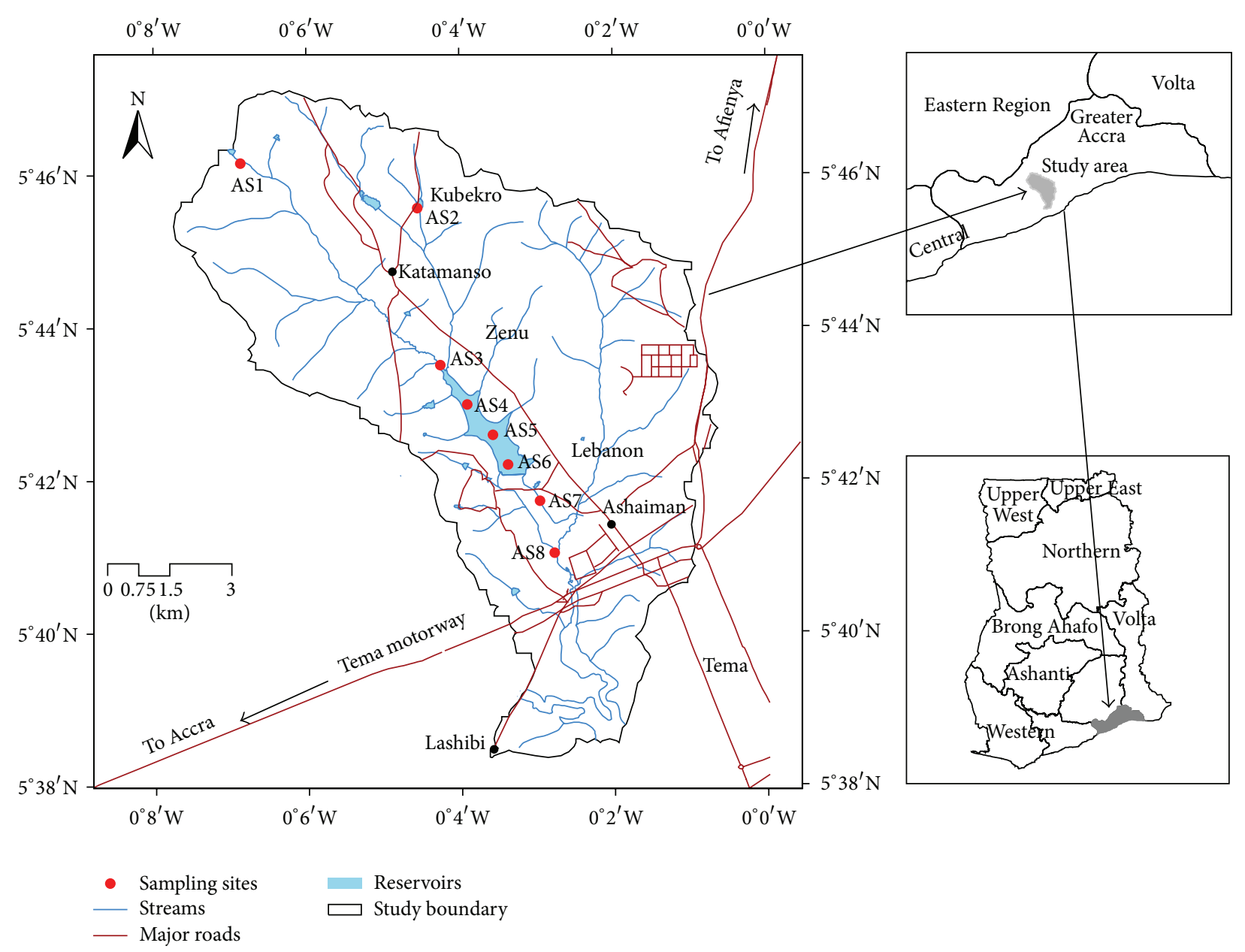

Figure 1: Map of the study area.

which was dammed into the Ashaiman irrigation scheme. These communities include Katamanso, Kubekro, Zenu, and Lebanon (Figure 1). While the first-three communities are located north of the irrigation scheme, Lebanon, on the other hand, shares boundary with the irrigated lands and for that matter has most farmers who work on the irrigated fields. The stream was dammed between Zenu and Lebanon and drained into the sea through the Sakumo Lagoon. Farmers cultivate different types of crops such as okra, cabbage, pepper, lettuce, maize, and rice for the urban markets. Crops such as cassava and maize are mainly cultivated at the upstream of the irrigation scheme.

2.2. Data Collection. A survey instrument was developed, pretested, and administered to 120 households which were involved in farming activities within the catchment of the stream. The distribution of households selected for the survey was 25 each from Katamanso and Kubekro, 30 from Zenu, and 40 from Lebanon based upon population of farming households in the communities. Households were randomly sampled from houses that had been selected systematically through the sampling of every 5 th house in each community starting from the northernmost house of the community using a handheld Garmin Global Positioning System (GPS) navigator (Garmin Inc., Kansas, USA). Final selection of households was based on engagement in crop cultivation. The survey instrument solicited information on ownership of farm(s), types of crops cultivated, sources of information on pesticides, sources of pesticides, knowledge on pesticides, and frequency of use of pesticides among others. Two focus group discussions (FGDs) were organized for further information to augment what was gathered through the survey. Selected farmers from the two upstream communities, Kubekro and Katamanso, were organized for the first FGD. The second FGD was organized for Zenu and Lebanon which were in the midstream and downstream, respectively. Observations were also made on use of protective clothes during spraying of pesticides and on the disposal of pesticides containers after use. The importance of the survey was explained to the farmers and their consent was sought before its administration.

2.3. Data Analysis. The Statistical Package for Social Sciences (SPSS) version 16 (SPSS Inc., Chicago, IL) was used in capturing, cleaning, and analyzing the data. All charts and tables were drawn using Microsoft excel 2007 and GraphPad 
TABLE 1: Farmer's personal information.

\begin{tabular}{|c|c|c|c|c|c|}
\hline \multirow{2}{*}{ Characteristics } & \multirow{2}{*}{ Variable (\%) } & \multicolumn{4}{|c|}{ Community } \\
\hline & & Kubekro & Katamanso & Zenu & Lebanon \\
\hline \multirow{2}{*}{ Gender } & Male & 60.0 & 52.0 & 56.7 & 52.5 \\
\hline & Female & 40.0 & 48.0 & 43.3 & 47.5 \\
\hline \multirow{6}{*}{ Educational status } & None & 16.0 & 32.0 & 20.0 & 20.0 \\
\hline & Primary & 16.0 & 28.0 & 40.0 & 30.0 \\
\hline & Middle/JSS & 32.0 & 16.0 & 40.0 & 20.0 \\
\hline & Secondary & 24.0 & 8.0 & 16.0 & 17.5 \\
\hline & Postsecondary & 8.0 & 16.0 & 4.0 & 7.5 \\
\hline & Tertiary & 4.0 & 0.0 & 0.0 & 5.0 \\
\hline \multirow{6}{*}{ Age group } & Below 20 & 8.0 & 16.0 & 16.7 & 12.5 \\
\hline & $20-29$ & 28.0 & 16.0 & 16.7 & 20.0 \\
\hline & $30-39$ & 32.0 & 20.0 & 20.0 & 20.0 \\
\hline & $40-49$ & 20.0 & 20.0 & 26.7 & 17.5 \\
\hline & $50-59$ & 8.0 & 16.0 & 6.7 & 12.5 \\
\hline & $60+$ & 4.0 & 12.0 & 13.3 & 17.5 \\
\hline$N$ & 120 & 25 & 25 & 30 & 40 \\
\hline
\end{tabular}

Prism (GraphPad Prism, GraphPad Software, San Diego, CA, USA). Using content analysis techniques, various themes which espoused the views of farmers were derived from the FGDs.

\section{Results}

3.1. Background of Farmers. The background characteristics of the 120 farmers who responded to the survey are presented in Table 1. Forty percent and $48 \%$ of the respondents from Kubekro and Katamanso, respectively, were females and $45 \%$ of all respondents were females. At least over $50 \%$ of all respondents had up to secondary education while about $22 \%$ had no education. With regard to age distribution, approximately $13 \%$ were below 20 and most (over 70\%) were between 20 and 60 years of age.

3.2. Ownership of Fields and Farming Practices among Respondents. Eighty percent (80\%) of respondents had only one, while $15 \%$ had two and $5 \%$ had three or more fields on which they farmed in the scheme area. Size of the farms varies with $76 \%$ below one hectare, $9 \%$ of approximately one hectare, and $6 \%$ between one and five hectares (Figure 2). Fortythree $(43 \%)$ percent of the respondents owned the fields they cultivated while $82.4 \%$ of those who did not own the fields cultivated them on leasehold and the rest cultivated them on sharecropping basis.

3.3. Types of Crops Cultivated by the Farmers and Cultural Practices. Types of crops grown by farmers include maize, cassava, vegetables, rice, and fruits. Fifty percent $(50 \%)$ of the respondents cultivated maize, $29 \%$ vegetables, $12.5 \%$ rice, and the rest cassava and fruits. Maize, cassava, and fruits were mainly grown in the upstream of the scheme, that is, in Katamanso and Kubekro, while vegetables were cultivated in midstream and downstream, in Zenu and Lebanon. Rice

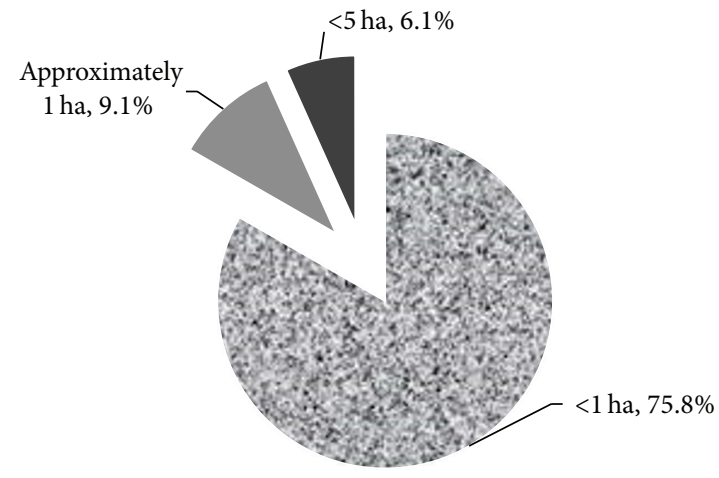

FIGURE 2: Average size of fields owned by respondents.

TABLE 2: Type of crop and size of farm.

\begin{tabular}{lcccc}
\hline Crop & \multicolumn{3}{c}{ Size of farm } & Total \\
& $<1$ ha & 1 ha & $>5$ ha & \\
\hline Maize & 39 & 11 & 8 & 58 \\
Rice & 15 & 0 & 0 & 15 \\
Vegetables/fruits & 40 & 0 & 0 & 40 \\
Cassava & 7 & 0 & 0 & 7 \\
\hline
\end{tabular}

was mainly cultivated in the downstream of the scheme at Lebanon area. Tomatoes, okra, and pepper were the main vegetables and watermelon was the main fruit grown in the study areas. Additionally, apart from maize which was cultivated on all sizes of farm, the rest of the crops were grown on less than one-hectare farmland (Table 2).

Herbicides were mainly used by $41.7 \%$ of the respondents to clear the lands of weeds for planting of crops, while $24.2 \%$ used slash and burn to control the weeds. About twenty-four percent $(24.2 \%)$ of the respondents used machines to plough the weeds with the soil, that is, if the weeds were not too 
TABLE 3: Type of pesticides in-use at various farm sites.

\begin{tabular}{lccccc}
\hline Pesticides & \multicolumn{5}{c}{ Percentages } \\
& Respondents & Lebanon & Kubekro & Katamanso & Zenu \\
\hline Cydim super & 5.8 & 0.8 & 3.3 & 1.7 & 0.0 \\
EC & & & & & \\
Round up & 35.0 & 60.0 & 0.0 & 0.0 & 8.0 \\
Gramoxone & 8.3 & 5.0 & 0.0 & 0.0 & 22.2 \\
Pawa & 3.3 & 2.5 & 0.0 & 0.0 & 8.3 \\
Dimethoate & 10.0 & 10.0 & 9.5 & 26.1 & 0.0 \\
Dursban & 0.8 & 2.5 & 0.0 & 0.0 & 0.0 \\
Karate & 11.7 & 7.5 & 14.3 & 21.7 & 8.3 \\
Master & 4.2 & 0.0 & 4.8 & 17.4 & 0.0 \\
Stam F34 & 1.7 & 2.5 & 0.0 & 0.0 & 2.8 \\
Topcope & 0.8 & 2.5 & 0.0 & 0.0 & 0.0 \\
Chemosate & 0.8 & 2.5 & 0.0 & 0.0 & 0.0 \\
\hline
\end{tabular}

grown. Results show that $66.7 \%$ and $62.5 \%$ of farmers in Zenu and Lebanon, respectively, were the main user of herbicides. On the other hand, majority (36.4\%) of the farmers who used machines to plough the weeds were from Kubekro. Rudimentary instruments such as hoes and cutlasses were the most used by $84.2 \%$ of the respondents for turning the soil. Almost 59\% of the respondents engaged in monocropping and $41.4 \%$ did crop rotation.

3.4. Pesticides In-Use in Ashaiman. Twelve different types of pesticides were in-use in Ashaiman and its environs. Thirtyfive percent of the respondents used round-up (glyphosate $41 \%$ ), while $8.3 \%$ used gramoxone (paraquat $276 \mathrm{~g} / \mathrm{L}$ ) for controlling weeds. Also $11.7 \%$ and $10 \%$ used karate (Lambdacyhalothrin $25 \mathrm{~g} / \mathrm{L}$ ) and dimethoate (dimethoate $400 \mathrm{~g} / \mathrm{L}$ ), respectively, for controlling insect pests. Topcope (sulphur $50 \%$ and copper sulphate $8.4 \%$ ) was the only fungicide in-use in the study areas. In exception of Master (Bifenthrin), all the pesticides were used by respondents in Lebanon suburb of Ashaiman where the irrigation fields are found. All those who used Dursban (Chlorpyrifosethyl $480 \mathrm{~g} / \mathrm{L}$ ) were in Lebanon. Five of the pesticides were used in Zenu and these include karate (Lambda-cyhalothrin $25 \mathrm{~g} / \mathrm{L}$ ), round-up (glyphosate 41\%), Stam F34 (Propanil $360 \mathrm{~g} / \mathrm{L}$ ), Pawa (Lambda-cyhalothrin $25 \mathrm{~g} / \mathrm{L}$ ), and gramoxone (paraquat $276 \mathrm{~g} / \mathrm{L}$ ). Only four of the pesticides were used in Kubekro (Topcope, Master, karate, and Cydim super EC) and Katamanso (Cydim super EC, gramoxone, dimethoate, and Master). Additionally, karate was used in all the communities (Table 3).

The pesticides were grouped into insecticides, herbicides, and fungicides. Insecticides and herbicides were mostly used compared to the fungicides. With regard to $\mathrm{WHO} / \mathrm{FAO}$ classification, most of the pesticides belong to category II of moderately hazardous chemicals (7/12), out of which 6 were insecticides. Indeed all synthetic insecticides belong to category II (Table 4).

3.5. Pesticide Application. Seventy percent (70\%) of the farmers had been using pesticides for over 5 years whereas only

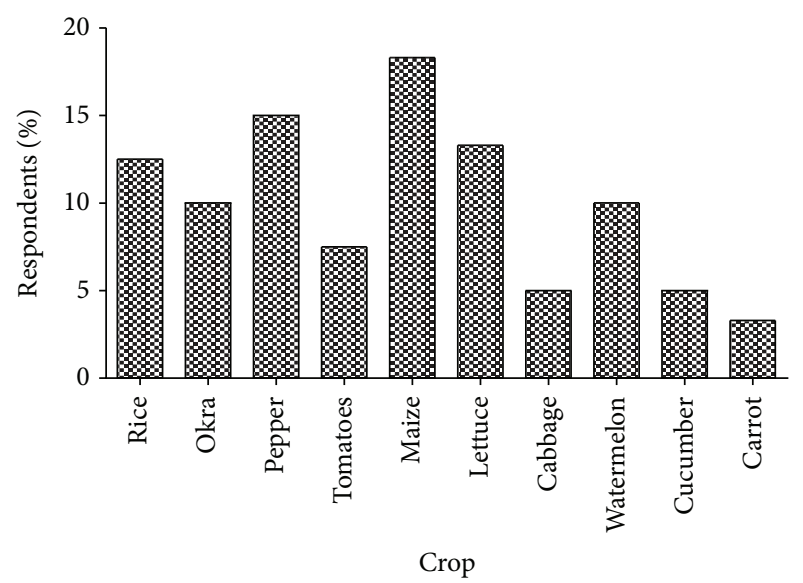

FIgURE 3: Crops to which pesticides were applied.

8.3\% did not use synthetic pesticides at all in their farming activities. Those who did not use the synthetic pesticides rather used natural repellants such as neem (Azadirachta indica) seed extracts to control pests. Though $80 \%$ of the respondents stated that the pesticides were readily available on sale in Ashaiman, only $35.8 \%$ found the pesticides to be affordable and as much as $51 \%$ found them to be too expensive.

The pesticides were applied to prepare the lands and to control pests of various crops (Figure 3 ). Over $18 \%$ of the farmers applied pesticides to maize farms, $15 \%$ to pepper, and $13 \%$ to lettuce. In the focus group discussions, the discussants mentioned that the frequency of application of pesticides depended first and foremost on farmer's ability to purchase the pesticide, followed by type of weed (if it is herbicide), type of crop, size of farm, and type of pests attacking the crops, in that order. Majority (34.2\%) of the respondents applied the pesticides twice while $28.3 \%$ applied them three times in a farming season. Another $28.3 \%$ applied them four or more times depending on the extent of infestation by pests. The data show that those who applied the pesticides more than three times cultivate less than one-hectare farms (Table 5). Quantity pesticides used among farmers ranged from $50 \mathrm{~mL}$ to $2000 \mathrm{~mL}$ per application. The first application of pesticides to crops by most respondents $(88.3 \%)$ occurs between 2 nd and 3rd weeks of planting. A second application is done, if it is necessary, normally in the 6 th and 7 th weeks as stated by $32 \%$ of the respondents. Other applications occurred as and when the farmers felt it was needed. It is worth noting that 5 th and subsequent applications were done for vegetables (Table 6).

Out of 74 farmers who were observed spraying pesticides on their farms, 36.5\% used nose guards, $45.9 \%$ used boots, $31 \%$ used hand gloves, and $25.7 \%$ wore dresses that covered the whole body except the eyes (Figure 4). Farmers were observed mixing different types of pesticides for spraying. The "cocktail" of pesticides, they believed, had increased potency for fast control of pests. The FGDs revealed that most farmers did not read and for that matter did not adhere to the instructions on how to apply the pesticides. They however received the information on the quantity of pesticides to use 
TABLE 4: Active ingredients in the pesticides used by farmers and WHO/FAO classification.

\begin{tabular}{|c|c|c|c|}
\hline Types of pesticides & Common name & Active ingredients & WHO/FAO classification \\
\hline \multirow{4}{*}{ Herbicides } & Stam F 34 & Propanil $360 \mathrm{~g} / \mathrm{L}$ & III \\
\hline & Round-up & Glyphosate $41 \%$ & III \\
\hline & Gramoxone & Paraquat $276 \mathrm{~g} / \mathrm{L}$ & II \\
\hline & Chemosate & Glyphosate $41 \%$ & III \\
\hline \multirow{7}{*}{ Insecticides } & Dimethoate & Dimethoate $400 \mathrm{~g} / \mathrm{L}$ & II \\
\hline & Dursban $4 \mathrm{E}$ & Chlorpyrifos-ethyl $480 \mathrm{~g} / \mathrm{L}$ & II \\
\hline & Pawa 2.5 EC & Lambda-cyhalothrin $25 \mathrm{~g} / \mathrm{L}$ & II \\
\hline & Cydim super & Dimethoate $400 \mathrm{~g}$ and cypermethrin $36 \mathrm{~g}$ & II \\
\hline & Karate 2.5 EC & Lambda-cyhalothrin $25 \mathrm{~g} / \mathrm{L}$ & II \\
\hline & Master & Bifenthrin & II \\
\hline & Neem seed extracts & Azadirachtin & $\mathrm{U}$ \\
\hline Fungicides & Topcope & Sulphur $50 \%$ and copper sulphate $8.4 \%$ & III \\
\hline
\end{tabular}

Note. II = moderately hazardous; III = slightly hazardous; $\mathrm{U}=$ unlikely to present acute hazard in normal use [9].

TABLE 5: Size of farm and frequency of application.

\begin{tabular}{lcccc}
\hline $\begin{array}{l}\text { Frequency of } \\
\text { application }\end{array}$ & $<$ ha & $\begin{array}{c}\text { Size of farm } \\
1 \text { ha }\end{array}$ & $>5$ ha & Total \\
\hline Once & 9 & 0 & 0 & 9 \\
Twice & 25 & 4 & 5 & 34 \\
Three times & 22 & 3 & 3 & 28 \\
Four times & 15 & 0 & 0 & 15 \\
5-10 times & 7 & 0 & 0 & 7 \\
More than 10 & 4 & 0 & 0 & 4 \\
times & 19 & 4 & 0 & 23 \\
Not & 101 & 11 & 8 & 120 \\
applicable* & & & & \\
Total &
\end{tabular}

${ }^{*}$ Not applicable refers to farmers who used neem seed extracts.

TABLE 6: Type of crop and frequency of application of pesticides.

\begin{tabular}{lccccc}
\hline $\begin{array}{l}\text { Frequency of } \\
\text { application }\end{array}$ & Vegetables & Maize & Rice & Cassava & Total \\
\hline Once & 2 & 3 & 3 & 1 & 9 \\
Twice & 8 & 16 & 5 & 6 & 35 \\
Three times & 7 & 19 & 4 & 0 & 30 \\
Four times & 7 & 5 & 0 & 0 & 12 \\
5-10 times & 6 & 0 & 0 & 0 & 6 \\
More than 10 & 5 & 0 & 0 & 0 & 5 \\
times & 5 & 15 & 3 & 0 & 23 \\
$\begin{array}{l}\text { Not } \\
\text { applicable* }\end{array}$ & 40 & 58 & 15 & 7 & 120 \\
Total & & & & & \\
\hline
\end{tabular}

${ }^{*}$ Not applicable refers to farmers who used neem seed extracts.

and how to apply them from the vendors, colleague farmers, and extension officers. Field observations showed that empty pesticide containers were thrown into nearby bushes after use. At least 16 out of 24 (66.7\%) of those whose chemicals got finished left the containers on their farm or threw them into

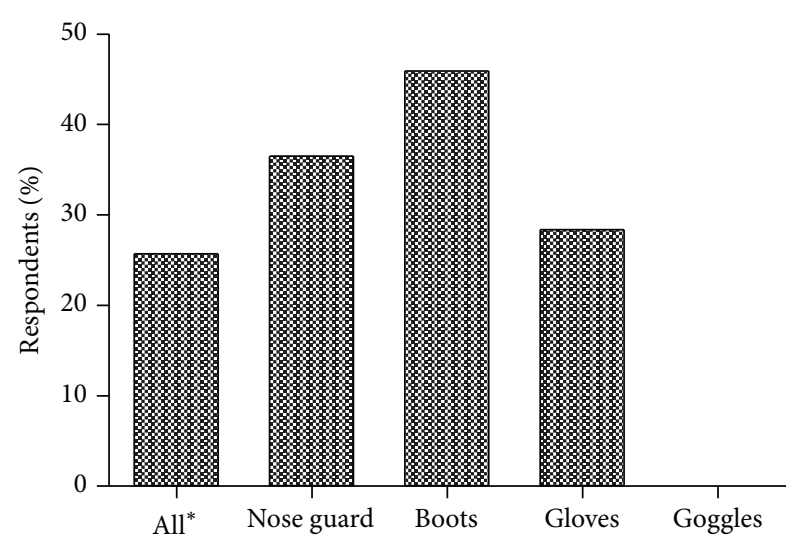

FIgURE 4: Personal protective equipment. * All gears except goggles.

the nearby bushes. On how the chemicals were preserved, most (86\%) farmers acknowledged keeping the chemicals in their homes and not on the field for fear of theft.

3.6. Sources of Information and Acquisition of Pesticide. Information on particular pesticides to use on crops was obtained from three sources. About forty-three percent (43.3\%) of the respondents had information about various pesticides through training programmes organized by agricultural extension officers. Also, 39.2\% of the respondents had information from agrochemical dealers in Ashaiman and its environs while $10 \%$ of them received theirs from colleague farmers. Most (75\%) of the respondents purchased the pesticides from agrochemical shops while $10.8 \%$ acquired theirs from other sources, such as friends and relatives.

\section{Discussion}

The importance of pesticides in modern agriculture cannot be overemphasized; however, use of pesticides comes with concerns regarding public and farmers' health as well as environmental pollution. Health problems associated with 
pesticide use, especially in farmers in developing countries, are well documented $[10,11]$. The data indicate that most of the farmers had attained levels of education that should enable them to read, in spite of the fact that many of them do not read the labels and instructions on pesticides before using them. They rather depend on the recommendation from chemical dealers, extension officers, colleagues, and sometimes their own intuition on how to apply the pesticides. The reason for this is not clear but it has been shown that farmers prefer to rely on pesticide sellers, extension officers, and peer farmers rather than reading instructions on or flyers attached to the chemicals [12]. The attitude of farmers in this study is similar to that studied by Alam and Wolff [12]. Therefore, equipping pesticide sellers with relevant and adequate information and involving them in farmer education on pesticide use will greatly complement the work of the extension workers [12].

Lack of adequate knowledge about pesticide use had reflected in the poor handling, frequency, and timing of application of the chemicals with serious health consequences. The farmers mentioned that the frequency of application of pesticides depends first and foremost on farmer's ability to purchase the pesticide, followed by type of weed, type of crop, size of farm, and type of pests attacking the crops, in that order. In spite of the above the quantity of pesticides used per application among respondents ranged from $50 \mathrm{~mL}$ to $2000 \mathrm{~mL}$, indicating that there could be underdoses or overdoses depending on the size of the field. The results show that those who applied the pesticides more than three times cultivated farms less than one hectare in size. A small farm actually favours the foremost factor that influences the frequency of application, that is, the ability to afford to pay for the pesticides. Obviously, those having small farms would like to keep productivity high as well and they do this by frequent use of chemicals [13]. This implies that access to bigger farms may be an antidote to indiscriminate use of pesticides.

Most commonly used pesticides were herbicides and insecticides with a minimal use of fungicides. Insecticide use was higher among the vegetables, maize, and rice farmers than cassava. Herbicide use was high among rice farmers and the reason for that is high cost and nonavailability of farm labour in the urban areas. The use of protective clothes among farmers was low as reported in other parts of the country and elsewhere $[7,8]$. The results show that most of the pesticides and all the synthetic insecticides were category II chemicals. Though in applying categories I and II chemicals farmers were supposed to wear appropriate personal protective equipment that covers the entire body [14], only $26 \%$ of the farmers covered their body except the eyes when applying the pesticides. Additionally, less than $50 \%$ of the farmers used either of the protective equipment items such as nose guards, boots, and gloves while none used goggles. This shows that the farmers had dangerously exposed themselves to the toxic chemicals. Some of the pesticides, for example, organophosphate pesticides such as dursban, are known to have negative consequence on proper functioning of the nervous system $[15,16]$. Additionally, it is emerging that glyphosate (the active ingredient in round-up, the most commonly used pesticide in the study area), which was thought to be not harmful to humans and animals, is actually harmful. Among others, glyphosate is now associated with cancer and known to destroy beneficial bacteria in humans, thereby allowing pathogenic ones to overgrow and overwhelm the body $[17,18]$.

The data also indicate the need to educate farmers on the mode of storage of pesticides and disposal of pesticide wastes. High numbers of farmers store their chemicals at home and this could lead to increase in morbidity or injury rate among farmers' families. The disposal methods are of equal concern since these can affect the larger community resulting from leaching of the pesticides into water bodies, which can lead to accidental ingestion.

\section{Conclusions}

In order to maximize output on the limited land, farmers are bent on practicing modern agricultural methods including the use of pesticides to protect their crops from pest damage. There is therefore the need to increase the number of extension officers to educate farmers on the right use of pesticides, and equipping pesticide sellers with relevant information and involving them in farmer education on pesticide use will complement the work of the extension workers. It would be prudent for the Environmental Protection Agency to monitor the proper disposal of pesticide containers to avert poisoning and environmental pollution.

\section{Conflict of Interests}

The authors declare that there is no conflict of interests regarding the publication of this paper.

\section{Authors' Contribution}

All authors contributed equally to the development of the concepts, data collection and analysis, and writing of the paper.

\section{Acknowledgments}

The study was funded by United Nations Development Programme (UNDP) and Centre for African Wetlands, University of Ghana, Legon.

\section{References}

[1] Ghana Statistical Service (GSS), Statistics for Development and Progress; National Accounts Statistics, Ghana Statistical Service (GSS), 2014, http://www.statsghana.gov.gh/docfiles/ GDP/GDP_2014.pdf.

[2] CIA World Factbook, "Economy," December, 2015, https://www .cia.gov/library/publications/the-world-factbook/geos/gh.html.

[3] D. Horna, M. Smale, R. Al-Hassan, J. Falck-Zepeda, and S. E. Timpo, "Insecticides use on vegetables in Ghana: would GM seed benefit farmers?” IFPRI Discussion Paper 007855, 2008.

[4] A. Gerken, A. Suglo, and M. Braun, Crop Protection Policy in Ghana, Integrated Crop Protection Project, PPRSD/GTZ, Accra, Ghana, 2001. 
[5] W. J. Ntow, H. J. Gijzen, P. Kelderman, and P. Drechsel, "Farmer perceptions and pesticide use practices in vegetable production in Ghana," Pest Management Science, vol. 62, no. 4, pp. 356-365, 2006.

[6] K. Asante and W. Ntow, "Status of environmental contamination in Ghana: the perspective of a research scientist," in Interdisciplinary Studies on Environmental Chemistry, Y. Obayashi, T. Isobe, A. Subramanian, S. Suzuki, and S. Tanabe, Eds., pp. 253-260, 2009.

[7] G. Owusu-Boateng and K. K. Amuzu, "A survey of some critical issues in vegetable crops farming along River Oyansia in Opeibea and Dzorwulu, Accra-Ghana," Global Advanced Research Journal of Physical and Applied Sciences, vol. 2, no. 2, pp. 24-31, 2013, http://beta.garj.org/garjpas/pdf/2013/ september/Boateng\%20and\%20Amuzu.pdf.

[8] A. A. Jamali, A. R. Solangi, N. Memon, and S. M. Nizamani, "A current scenario of pesticide practices among farmers for vegetable production: a case study in Lower Sindh, Pakistan," International Journal of Development and Sustainability, vol. 3, no. 3, pp. 493-504, 2014, http://www.isdsnet.com/ijds.

[9] World Health Organization (WHO. The WHO Recommended Classification of Pesticides by Hazard and Guidelines to Classification, IPCS/IOMC. A Cooperative agreement among FAO, ILO, UNEP, UNIDO, UNITAR, WHO \& OECD, 2009.

[10] International Labour Organisation (ILO), Safety and Health in the Use of Agrochemicals: A Guide, An ILO Contribution to the International Programme on Chemical Safety (A Collaborative Programme of the United Nations Environment Programme, the International Labour Organisation and the World Health Organization), International Labour, 1991, http://www.ilo.org/wcmsp5/groups/public/@ed_protect/@protrav/@safework/documents/instructionalmaterial/wcms_110196 .pdf.

[11] S. J. Miah, A. Hoque, A. Paul, and A. Rahman, "Unsafe use of pesticide and its impact on health of farmers: a case study in Burichong Upazila, Bangladesh," Journal of Environmental Science, Toxicology and Food Technology, vol. 8, no. 1, pp. 57-67, 2014.

[12] S. A. Alam and H. Wolff, "Do Pesticide Sellers Make Farmers Sick? Health, Information Sources and Adoption of Technology in Bangladesh," 2014, http://faculty.washington.edu/ hgwolff/AlamWolff.pdf.

[13] W. Aktar, D. Sengupta, and A. Chowdhury, "Impact of pesticides use in agriculture: their benefits and hazards," Interdisciplinary Toxicology, vol. 2, no. 1, pp. 1-12, 2009.

[14] Montana State University, "Personal Protective Equipment (PPE) for Pesticide Applicators," 2005, http://www.pesticides .montana.edu/reference/ppe.htm.

[15] Y. Yurumez, P. Durukan, Y. Yavuz et al., "Acute organophosphate poisoning in university hospital emergency room patients," Internal Medicine, vol. 46, no. 13, pp. 965-969, 2007.

[16] V. Pandit, S. Seshadri, S. N. Rao, C. Samarasinghe, A. Kumar, and R. Valsalan, "A case of organophosphate poisoning presenting with seizure and unavailable history of parenteral suicide attempt," Journal of Emergencies, Trauma and Shock, vol. 4, no. 1, pp. 132-134, 2011.

[17] A. J. De Roos, A. Blair, J. A. Rusiecki et al., "Cancer incidence among glyphosate-exposed pesticide applicators in the Agricultural Health Study," Environmental Health Perspectives, vol. 113, no. 1, pp. 49-54, 2005.
[18] Gut-Wrenching New Studies Reveal the Insidious Effects of Glyphosate, June 2015, http://articles.mercola.com/sites/ articles/archive/2014/04/15/glyphosate-health-effects.aspx. 


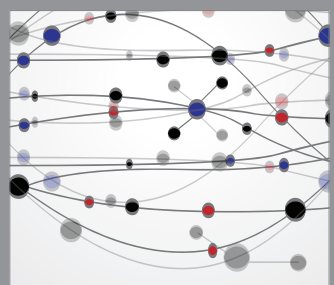

The Scientific World Journal
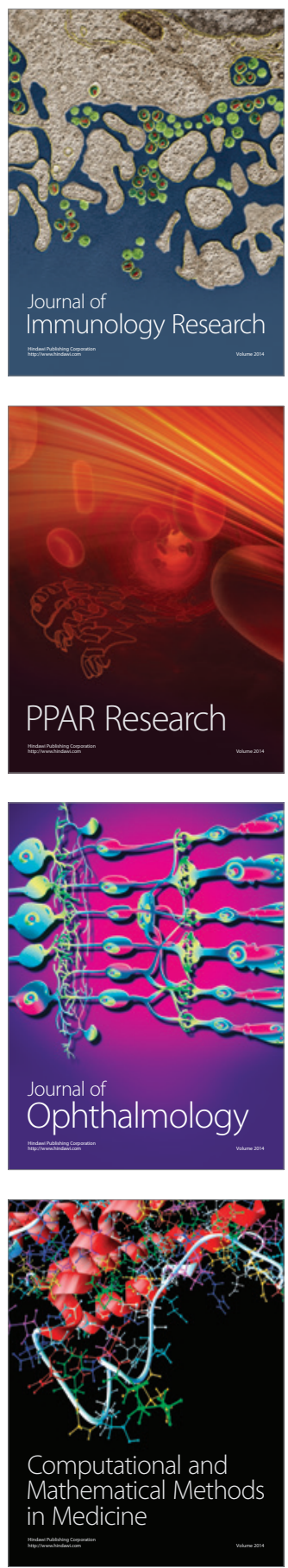

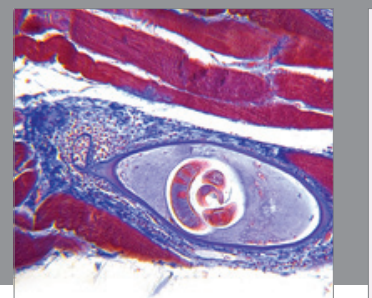

Gastroenterology

Research and Practice
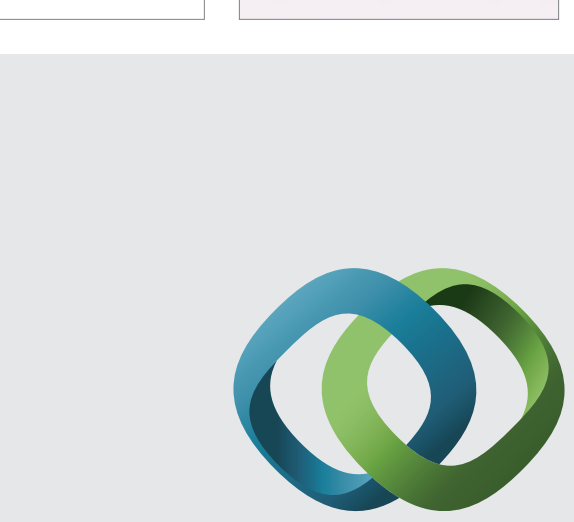

\section{Hindawi}

Submit your manuscripts at

http://www.hindawi.com
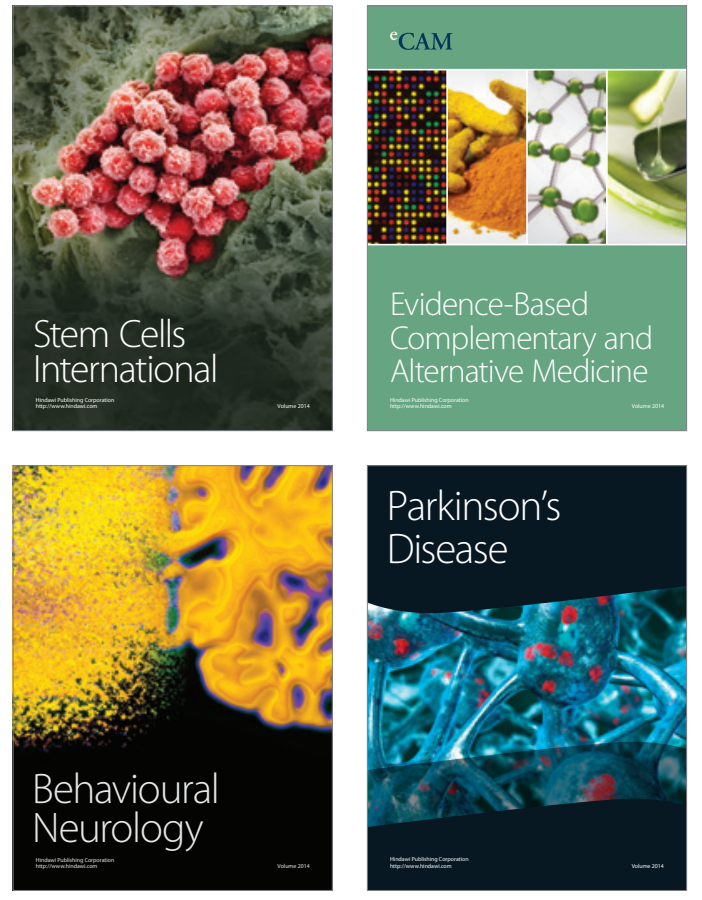
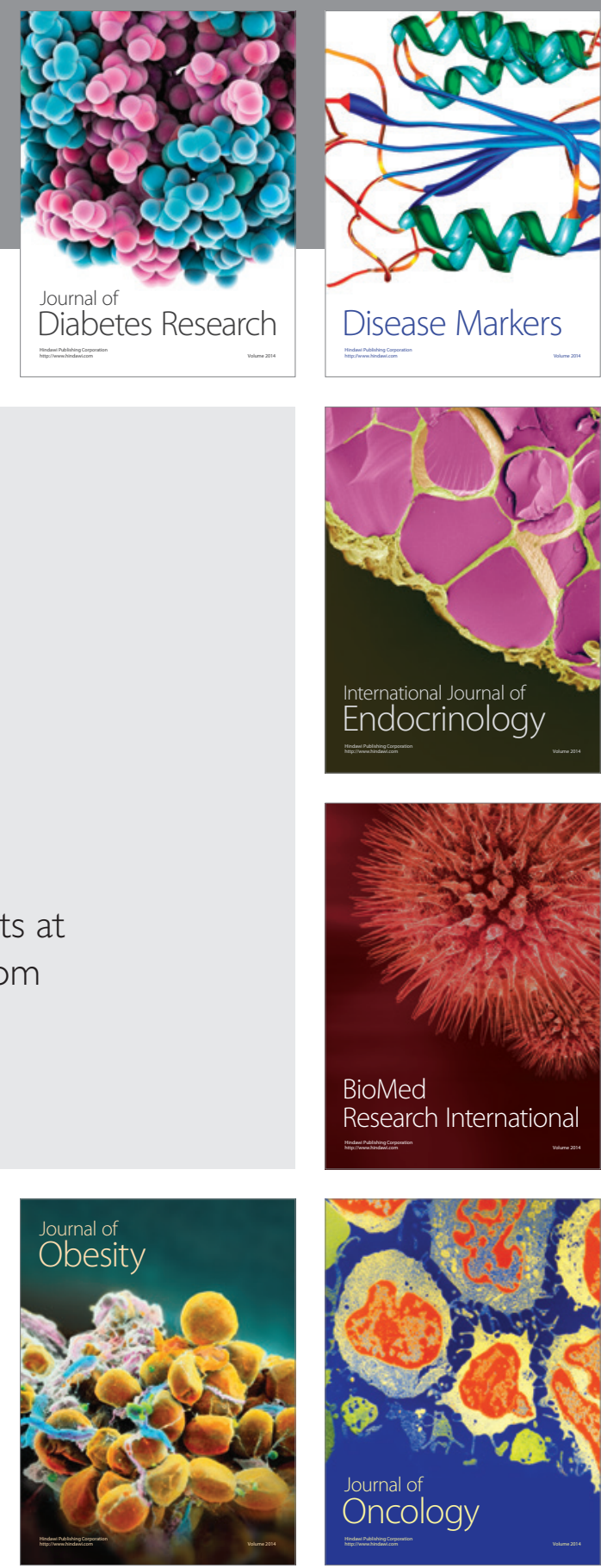

Disease Markers
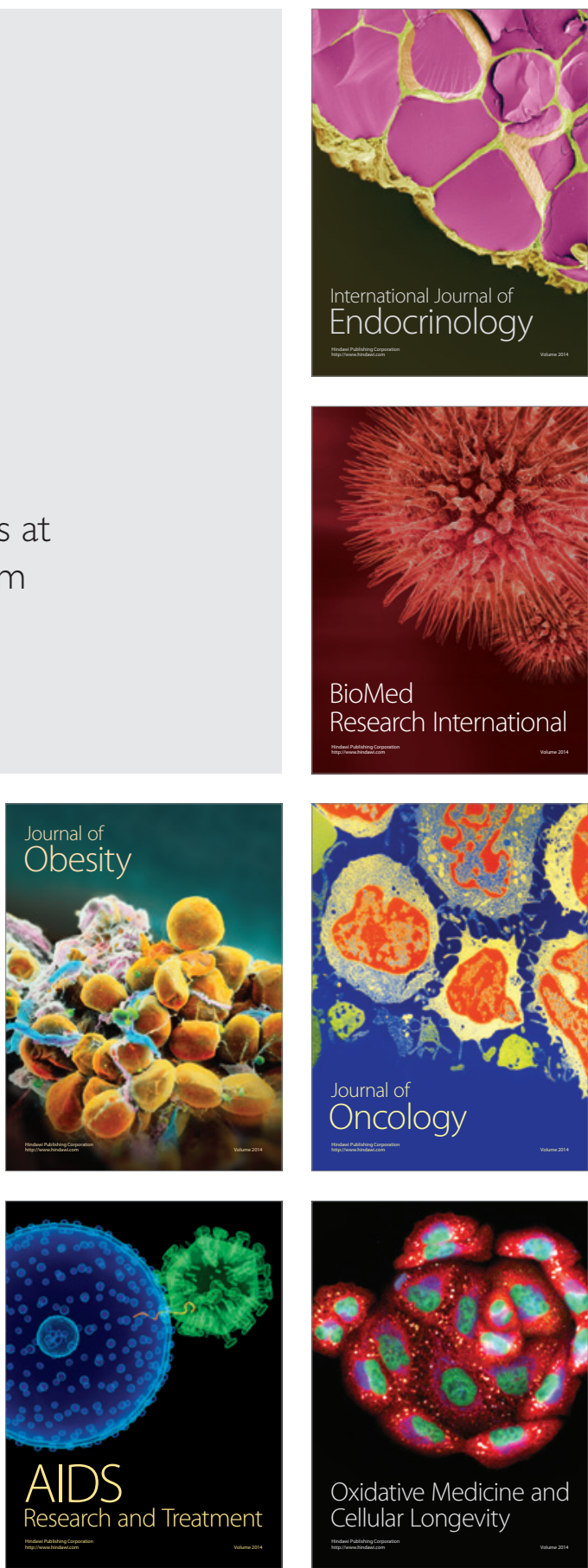